34. The External Characters of Scarturus and other Jerboas, compared with those of Zapus and Pedetes. By R. I. Pocock, F.R.S., F.Z.S.

[Received May 9, 1922 : Read May 23, 1922.]

(Text-figures 29-37.)

\begin{tabular}{|c|c|}
\hline Introduction & $\begin{array}{r}\text { Page } \\
659\end{array}$ \\
\hline External Appearance & 660 \\
\hline The Rhinarium and Mouth & 661 \\
\hline Facial Vibrissæ & 663 \\
\hline The Ear .... & 664 \\
\hline The Fore Foot. & 667 \\
\hline The Hind Foot & 670 \\
\hline Tails ................ & 674 \\
\hline Anus and External Genitalia & 675 \\
\hline The Skull of Scarturus........ & 678 \\
\hline The Genus Scirtopoda Brandt & 679 \\
\hline Conclusions . & 680 \\
\hline
\end{tabular}

\title{
INTRODUCTION.
}

At the Scientific Meeting of the Zoological Society held on May 24th of last year (P.Z.S. 1921, p. 645), Major Flower exhibited examples of three species of Egyptian Jerboas (Jaculidæ), including a pair of the very rare four-toed form, Scarturus tetradactylus, which had never been previously imported to Europe alive, and was almost unknown in museums, apart from the original example in Berlin, which was described as Dipus tetradactylus by Lichtenstein in 1823. These examples were exhibited in the Zoological Gardens for some months, but died in the winter and came into my hands for examination*. To compare with them I had several specimens of the two common Egyptian Jerboas (Jaculus jaculus and Scirtopoda orientalis) $\uparrow$; and also one of the five-toed genus Allactaga (A. indica), a pair of examples of Zapus hudsonianus or a nearly related species, and one male specimen of Pedetes caffer-the last-mentioned examples having been preserver for many years in alcohol in the Society's collection. The specimens above mentioned form the material upon which this paper is principally based.

* Although apparently fully adult when received, all the skeletal tissues at the time of death were exceedingly frail. Even the tips of the incisor teeth were uncalcified and pliable - a condition I never before observed in any mammal.

+ Good figures, drawn from life, and descriptions of these, as well as a brief account of S. tetradactylus, may be found in Anderson and de Winton's 'Mammalia of Egypt.' My reasons for adopting the name Scirtopoda are given below (p. 679).

Proc. Zool. Soc.-1922, No, XLV. 45 
That Zupus belongs to the same group of Rodents as Jaculus has long been admitted, and is disputed, so far as I am aware, by no one acquainted with this order. The evidence rests mainly upon certain cranial characters connected more particularly with the zygomatic arch and the preorbital foramen, the structure of which distinguishes that genus from the Muridæ, despite the generally murine shape of the skull. It is also conceded that Sicista, formerly knoẉn as Sminthus, is tolerably closely related to Zapus. With regard to Pedetes, my pretext for including that genus in this paper is its former ascription to the same section* as Zapus and Jaculus, although now recognised as representing a quite distinct family, sometimes associated with the Hystricomorpha, together with the family Anomaluridæ.

\section{External Appearance.}

The general appearance of Sicista and Zapus may be described as murine. They have a long mouse-shaped head and comparatively small diurnal eyes, and, although the hind legs of Zapus are elongated and saltatorial, they are not very much longer relatively than in our common wood-mouse, Apodemus sylvaticus. The Jerboas, on the other hand, are not the least like typical murine rodents in appearance. The head is very large, wide, and, as a rule, short especially in the snout, which is deep from above downwards, and the eyes are relatively enormous and nocturnal. The hind legs are of great length and the fore limbs are short. A Jerboa with the fore limb, measured from the elbow, of approximately the same length as that of a Zapus has the foot, measured from the heel, about twice as long as that of Zapus. Hence, when progressing on all fours, the gait of a Jerboa is exceedingly awkward, owing to the great elevation of the hind quarters. They seldom adopt that mode of progression, usually employing their hind legs alone. When moving at speed they take prodigious hops, like a Kangaroo; but they frequently go at a more leisurely pace, trotting or striding along like an ostrich or a human being; an action of which Kangaroos, and, presumably, Zapus also, are quite incapable.

The great variation in the size of the ears affects the appearance of different species of Jerboas when compared with one another. They also differ in the shape of the muzzle. As above stated, the muzzle is typically short and truncated; but in Euchoreutes, hence named naso, it is relatively long. Presumably also Allactaga, although I have never seen a living example, must have a differently shaped muzzle from Jaculus on account of the prominence of the upper incisor teeth, which form an angle instead of, as in Taculus, a continuous curve with the nose. Scarturus is intermediate between the two genera just mentioned with respect to the direction of these teeth.

* See Flower and Lydekker's 'Mammals, Living and Extinct,' p. 480 (1891). 
The Rhinarium and Mouth.

In Zapus the rhinarium is well defined and marked by a distinct vertical groove, formed by the thickened bulging upper and inner margin of the nostrils. Above the thickening of the upper rim there is a short transverse area. The area below the rhinarium, extending from the nostrils to the edge of the

Text-figure 29.

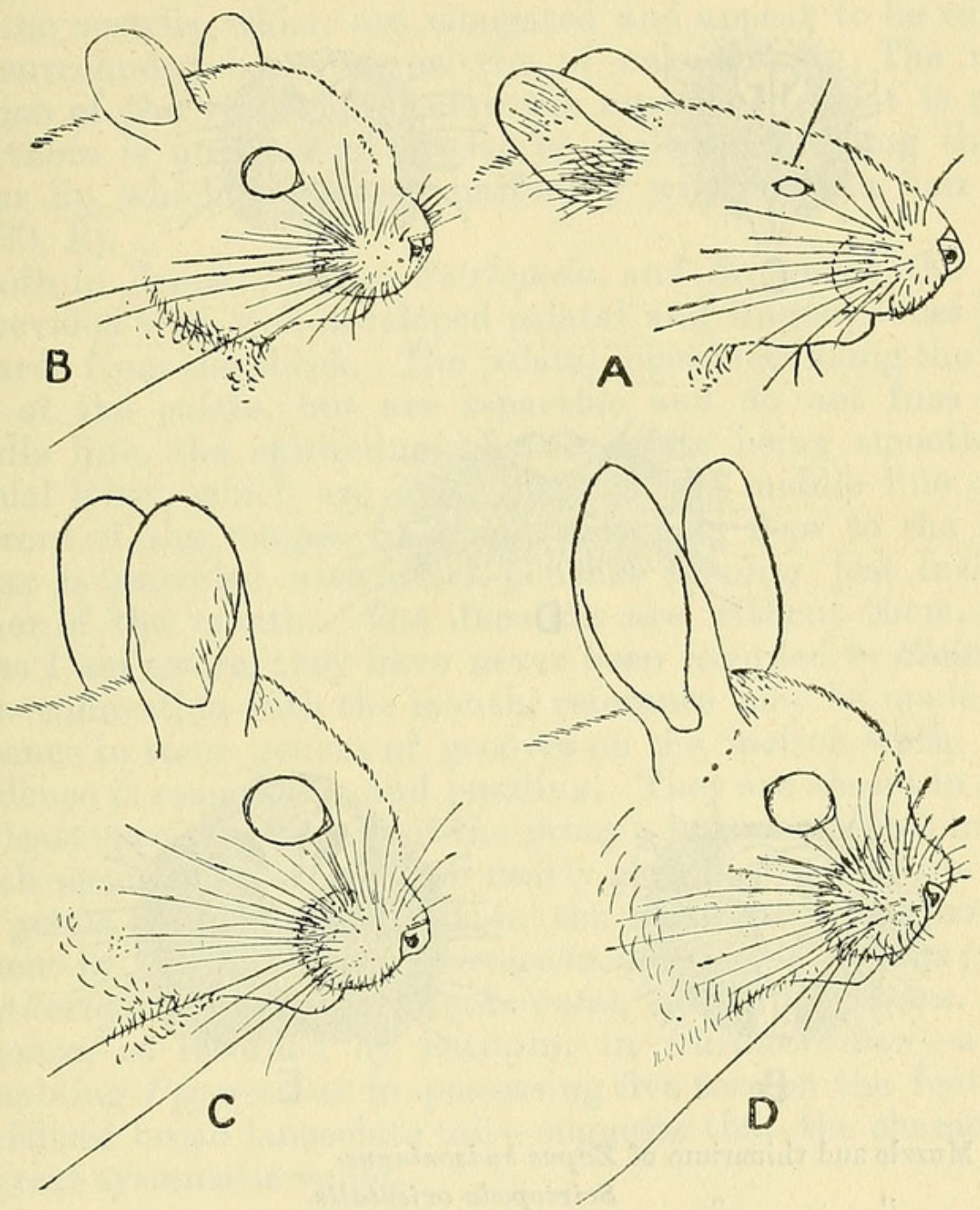

A. Head of Zapus hudsonianus.

B. „ Jaculus jaculus.

C. " Scirtopoda orientalis.

D. „ Scarturus tetradactylus.

upper lip, is covered with shorter hair than the rest of the muzzle. There is no sign of a groove or philtrum dividing the upper lip in the middle line. (Text-fig. 30, A.)

From Miller's description of the rhinarium of Sicista loriger (Cat. Mamm. Western Europe, p. 537, 1912), it seems that the muzzle resembles in general features, at all events, that of $Z$ apus, 
He describes the anterior border of the nostril as thickened, with a small wart beneath it [? the nostril], and the space between the nostrils as narrow, marked by a well-developed vertical ridge, and the upper lip as having no groove in front.

In Jaculus, Scirtopodu, and Scarturus the rhinarium is very like that of Zapus, showing a similar thickening of the upper and inner rim and a median groove, but the area below the rhinarium

\section{Text-figure 30.}
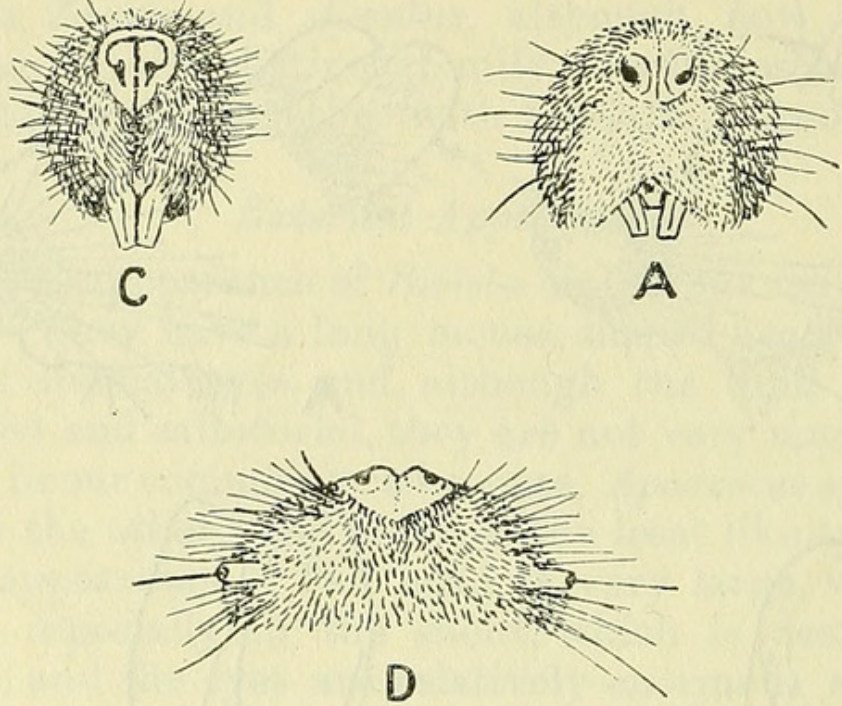

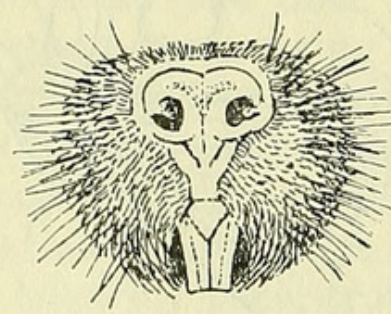

B

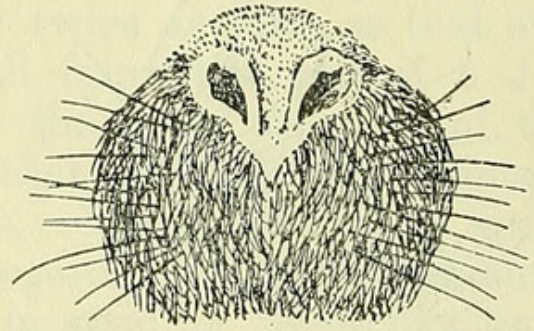

E

A. Muzzle and rhinarium of Zapus hudsonianus.

B. " " Scirtopoda orientalis.

C. The same, contracted.

D. Muzzle and rhinarium of Jaculus jaculus, to show especially the papillæ, slightly enlarged and cleared of hair, carrying the long stout vibrissæ.

E. Muzzle and rhinarium of Pedetes caffer.

in the middle line is naked and constitutes a kind of shallow philtrum. Of the muzzle of this genus, Anderson and de Winton said:- "Over the bare area of the nose of Jaculus there is a thickened fold of skin capable of being drawn forwards, so as almost to cover the nostrils, this structure serving to protect them when the animal is using its broad snout to push out the earth 
when digging its burrow" (Mamm. Egypt,p. 304). The rhinarium when thus partially concealed also contracts very perceptibly, the nostrils are approximated and assume a more vertical appearance, and the philtrum is obliterated by the median juxtaposition of the two halves of the upper lip. This device probably serves to exclude fine blown sand, as well as the soil when digging is in operation. (Text-fig. 30, B, C.)

The rhinarium of Pedetes is quite unlike that of Zapus and Jaculus. It is covered above and in front with fine short hair; but the nostrils, which are elongated and appear to be valvular, are surrounded by a narrow rim of naked skin. The median portion of the rhinarium below the nostrils in front is angled, but there is no trace of groove or philtrum dividing the deep upper lip, which is covered uniformly with longish hair (textfig. 30, E).

Both in Zapus, Jaculus, Scirtopoda, and Scarturus, the mouth is provided with well-developed palatal and lingual lobes jutting inwards from the cheek. The palatal lobes meet along the middle line of the palate, but are separable and do not fuse in the middle line, the epithelium of the palate being smooth. The lingual lobes, which are long, meet in the middle line over or in front of the tongue, forming a secondary floor to the mouth. Zapus is provided with cheek-pouches opening just inside the corner of the mouth. The Jaculide are without them, and, so far as I am aware, they have never been recorded in Sicista.

In connection with the mouth, reference may be made to the presence in some genera of grooves on the incisor teeth. Their incidence is remarkable and puzzling. They are absent in Sicista, the least specialised genus of the group; but are present in Zapus, which seems to be much more nearly akin to Sicista than it is to any genus of Jaculidæ. Within the Jaculidæ, the grooves are present in Dipus, Jaculus, Scirtopoda, and Cardiocranius ; absent in Allactaga, Scarturus, Euchoreutes, and Pygeretmus. Their presence, as recorded by Satunin, in Cardiocranius - a genus resembling Pygeretmus in possessing five toes on the foot and a specialised broad lanceolate tail-suggests that the character has no great systematic value.

\section{Facial Vibrissce.}

The mystacial vibrissæe are well developed in Zapus. One or two long superciliary vibrissæ are also present; but in the long hairs clothing the cheek I failed to find the genal tuft. The interramal is represented by two very fine vibrissæ in one example. In the Jaculidæe the interramal tuft is apparently absent, and the superciliaries and genal tufts are of inconstant occurrence, and represented at most by one or two fine vibrissæ each. But the mystacials are well developed, one of them on each side set low down being stouter and longer than the rest. This 
peculiarity is not so well marked in Alluctaga and Scarturus as in Jaculus ; but the two common Egyptian Jerboas differ somewhat in this respect. In Scirtopoda orientalis this long bristle is distinctly stouter and stiffer than the rest, and rises from a small papillary root, whereas in $J$. jaculus the difference is considerably greater, and the papilla from which it arises is much larger. (Text-fig. 30, D.)

In Pedetes the mystacial vibrissa are comparatively few in number and short, although stout. A few longish superciliaries are present. The interramal tuft is apparently absent; but the genal is represented by two or three long vibrissæ set high up the cheek a little behind and below the posterior angle of the eye as in the Hystricomorpha.

By the characters mentioned above the genera may be arranged as follows:-

a. Rhinarium ill defined, covered with hair except immediately round the nostrils, which are not visibly swollen and have no median groove between them; superciliary and genal vibrissæ well developed; mystacials stout and comparatively short ................

$a^{\prime}$. Rhinarium well defined, naked, nostrils with swollen rim and a groove between them; superciliary and genal vibrissæ few or absent, mystacials long and slender for the most part.

$b$. Head narrow and low, murine in shape; no median groove on upper lip; mouth with cheek-pouches (? in Sicista) ...... Zapus, Sicista.

$b^{\prime}$. Head broad and high; upper lip divided by philtrum, no cheekpouches

Pedetes.

Jaculus, Scirtopoda, Scarturus*.

\section{The Ear.}

In Zapus the ear is moderately large and expanded, and arises from the head by a broad base which is not tubular. The anterior edge is normally overfolded, and inferiorly about on a level with the supratragus it is produced into a lamina which is normally folded inwards out of sight. The lower edge of this curves into the cavity of the ear and ceases on its floor. The tragus is represented by a small movable lobe, and the antitragus by a large tufted lamina which, when the ear is folded, projects forwards and closes the lower portion of the cavity. The orifice is situated just below and on the inner side of the deep intertragal notch. (Text-fig. 31, A-C.)

Miller describes the ear of Sicista loriger as " moderately large, extending a little beyond the eye when laid forward, its outline simple, ovate, its posterior border with large thickened lobe at base, capable of completely closing the meatus, its anterior border with minute though evident sub-basal notch and projection; both surfaces of ear densely clothed with short hairs; basal lohe conspicuously tufted." This description might have been taken

* I have not seen a sufficient number of specimens of Allactaga and other Asiatic genera of Jaculidæ to know whether the cleavage of the upper lip is a constant character in this group or not. 
from the ear of Zapus, with the anterior flap concealed, as is normally the case, by being folded inwards.

Text-figure 31.

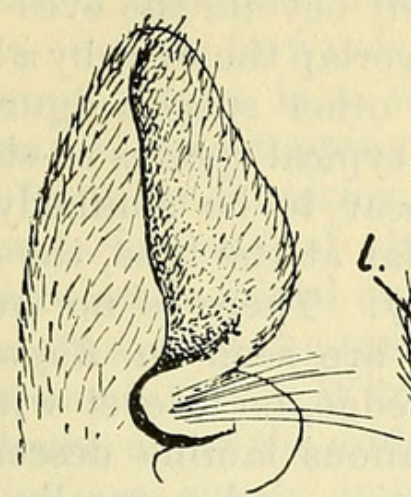

B
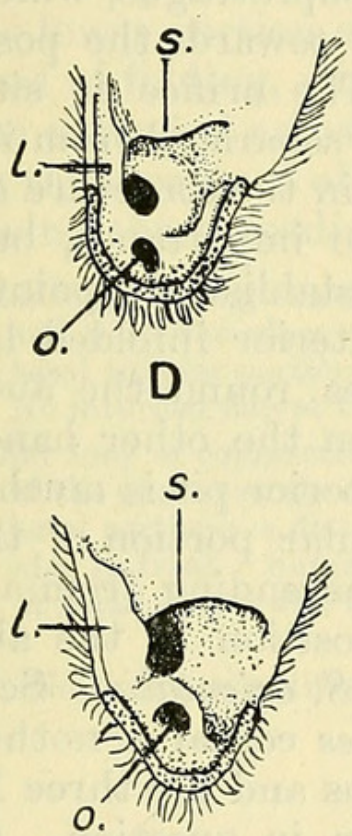

$E$
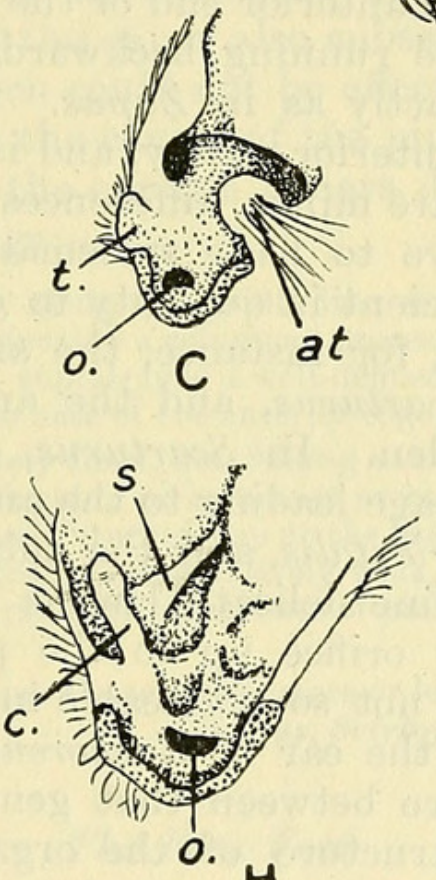

H

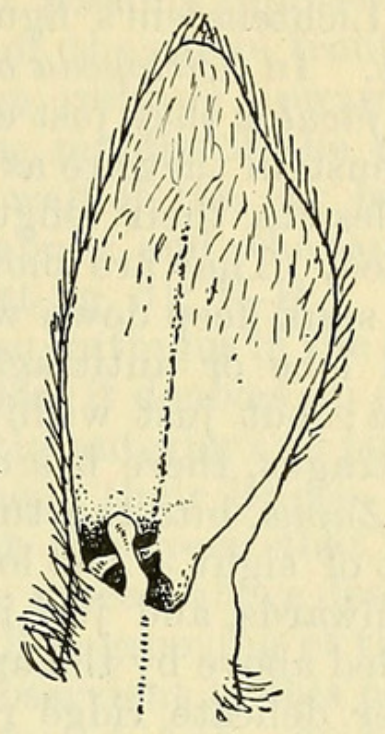

$\mathbf{F}$

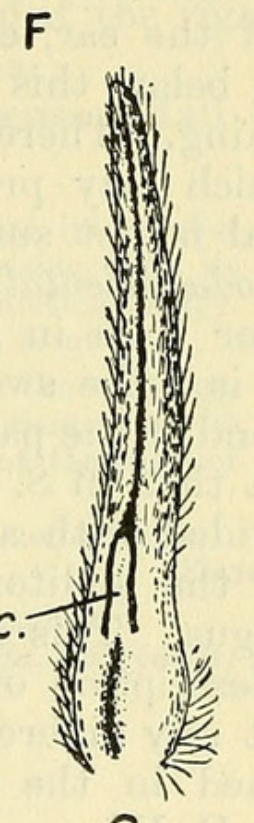

G

A. Ear of Zapus hudsonianus, expanded.

B. The same, contracted.

C. Base of ear of the same, with basal portion cut open between tragus and antitragus.

D. The same of Scarturus tetradactylus.

E. The same of Scirtopoda orientalis.

F. Expanded ear of Pedetes caffer.

G. Folded ear of the same.

H. Base of the ear of the same, cut open.

$l$., infolded lamina of anterior border; $t$., tragus ; at., antitragus; $s$., supratragus ; $o$., orifice of ear; $c$., columuar process.

In the Jaculidæ the ears vary greatly in length. In Euchoreutes, the longest-eared form, they considerably overlap the tip of the exceptionally long snout, when turned forwards. In 
Scarturus, which has a short snout, they surpass it by a little. In Allactaga indica they reach about to the end of the muzzle, and in most species assigned to this genus they appear, judging from Lichtenstein's figures, to reach well beyond the eyes at all events. In Scirtopoda orientalis they overlap the eyes by a little; in $J$. jaculus they just cover them. In other species figured by Lichtenstein they are as short as in the typical species or shorter. But despite their length they all appear to be similarly constructed. They are more or less tubular at the base, the orifice being sunk deep down within the cavity. There is no trace of tragal lobe or antitragal flap, such as are seen in Zapus and Sicista; but just within the anterior edge, on a level with the supratragus, there is a delicate membranous lamina descending, as in Zapus, into the tubular basal portion and normally folded in out of sight. The lower end of this lamina curves backwards and inwards, and just inside its lower end there is a deep cavity bounded above by the anterior end of the supratragus, which is a slender delicate ridge running backwards towards the posterior edge of the ear, exactly as in Zapus. The orifice is situated a little below this anterior cavity, and is separated from it by a thickening. There are minor differences in the structure of the ear which may prove to have systematic importance, but my material is not sufficient in quantity to establish the point. In Scirtopoda orientalis, for instance, the anterior infolded lamina is larger than in Scarturus, and the area round the auditory orifice is more sivollen. In Scarturus, on the other hand, the lower end of the passage leading to the anterior pit is much more swollen than in $S$. orientalis, and the tubular portion of the ear is provided with a fine delicate lamina ascending from a point behind the auditory orifice up to the position of the aborted antitragus. This is not so noticeable in $S$. orientalis. Sclater's brief description of the ear of Euchoreutes contains nothing to suggest any difference between that genus and the three I have examined in the structure of the organ in question. (Textfig. 31, D, E.)

From what has been said above it will be clear that the kinship claimed to exist between Zapus and the Jaculidæ on cranial grounds is completely borne out by the ear. The ear of the Jaculidæ may be regarded as a derivative of the type seen in Zapus, specialised by its more tubular base, with which the disappearance of the tragus and antitragus is correlated. In the Jaculidæe, too, the anterior basal pit is deeper and its inferior edge is closer to the auditory orifice.

The ear of Pedetes is very different from those described above, although in its tubular base and its length it recalls in appearance the ear of some Jaculidæ. It shows, however, in its posterior border behind the tip, a shallow but long emargination, similar to the emargination so common in many of the Hystricomorpha. The anterior erige is not overfolded and there is no inturned lamina at the base. There is no antitragus, but from the inner side of 
the outer wall of the tubular base there arises a compressed process which projects upwards as a free outgrowth some little distance above the margin of the basal tubular portion. When the ear is expanded this process, which possibly represents the tragus, inclines forwards along the edge of the ear in front of it. The supratragus is a well-defined ridge running upwards and backwards, but stopping abruptly in the middle of the ear far away from its posterior edge; and the wall of the ear between the posterior end of the supratragus above and the auditory orifice below is folded and creased. (Text-fig. 31, F-H.)

The reason for the termination of the supratragus in the middle of the ear is this. When the ear is folded, it doubles up exactly length wise along the middle line, so that the anterior and posterior margins are evenly in contact throughout their length, except close to the basal tubular portion; but the space that is left between them at this spot is filled by the process above described, and that appears to be its function. The grooving of the wall of the lower portion of the ear is also subservient to this peculiar method of folding, which could not be effected if the rigid supratragus extended across the cavity of the pinna.

By the structure of the ear the genera discussed fall into the following three headings:-

a. Ear long, folding exactly along the middle line, so that its anterior and posterior edges coincide; a columnar process rising from its basal tubular portion; supratragus a well-defined thickened ridge. No inturned flap at the base of the anterior edge in front .........

Pedetes.

$a^{\prime}$. Ear long or comparatively short, not folding so that the two edges of the pinna exactly coincide; no columnar process rising from its basal portion ; a distinct inturned flap at the base of the anterior edge in front. Supratragus comparatively weak.

b. A small tragus and large antitragus, base of pinna not tubular.

Zapus, Sicista.

$b^{\prime}$. No tragus or antitragus; base of ear more or less tubular.

Jaculus, Scirtopoda, Scarturus, Allactaga.

\section{The Fore Foot}

In Sicista subtilis, judging from Tullberg's figure, the fore foot is comparatively broad, short, and unmodified; the four main digits are subequal in length, the third and fourth projecting a little beyond the second and fifth, the latter being a little shorter than the second; the first, or pollex, is quite short, and springs from the middle of the side of the foot close to the distal edge of the carpal pad. The digital pards are moderate in size and elliptical, and the claws are small. The plantar pad consists of three moderately large interdigital elements, subtriangular in shape and in contact or nearly so. The carpal pads are large, covering about half the area of the sole, the internal element being about twice the area of the external, which is in contact with it. (Text-fig. 32, B.)

The fore foot of $Z$ apus is comparatively long and narrow. The carpal pads and pollex are tolerably similar to those of Sicista, 
but the three interdigital elements of the plantar pad are small, obscurely defined, circular tubercles widely separated from each other. The four main digits, moreover, are longer and thinner than in Sicista aud unevenly spaced, the third and fourth being close together at the base, but the second is some distance from the third, and the fifth from the fourth. The claws are comparatively long, and the sole of the foot is granular. 'The foot is a slight exaggeration of the type seen in A podemus sylvaticus, the common

Text-figure 32.

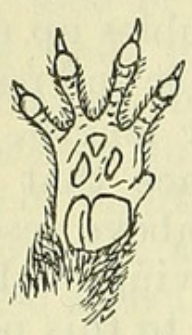

A

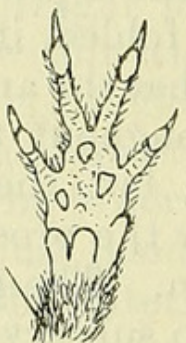

D

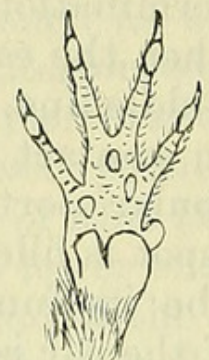

C

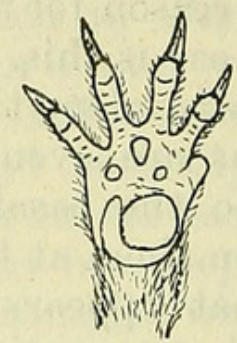

B

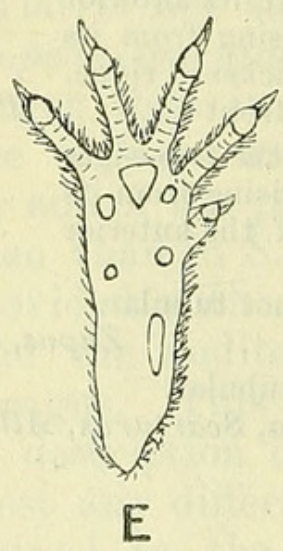

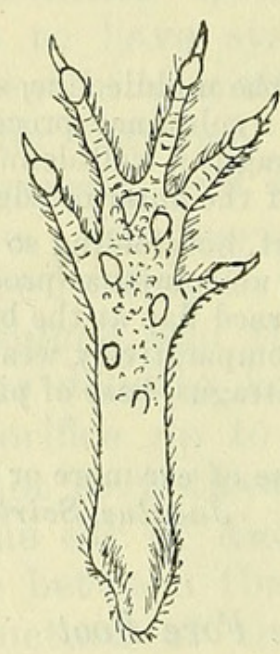

G

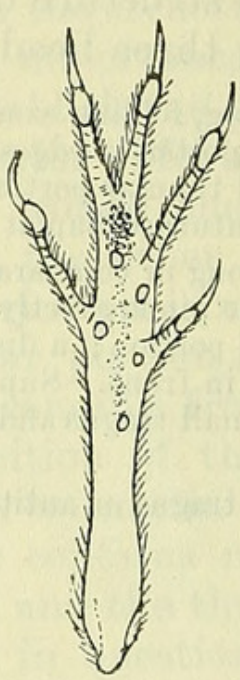

F

A. Right fore foot of Scarturus tetradactylus.

B. The same of Sicista subtilis (after Tullberg).

C. The same of Zapus hudsonianus.

D. The same of Apodemus sylvaticus, for comparison with C.

E. Right hind foot of Sicista subtilis (after Tullberg).

F. The same of Zapus hudsonianus.

G. The same of Apodemus sylvaticus, for comparison with F.

English wood-mouse, the third and fourth digits being conjointly a little more removed from the second and fifth. (Text-fig. 32, C.)

The fore feet of the Jerboas (Jaculida) seem to resemble very closely those of Sicista in a general way, except that the claws are much longer, being generally very long, and the interdigital elements of the plantar pad greatly reduced in size. In Scarturus they are represented by three widely separated circular papillæ; 
in Euchoreutes, according to Sclater: there are only two, corresponding apparently to the median and outer of Scarturus; in Allactaga indica I can find only the median remaining, whereas in Scirtopoda orientalis and $J$. jaculus all definite trace of them seems to have disappeared, the sole of the foot in front of the carpal pads being merely marked by integumental creases. As in Sicist and Zapus, the carpal pad is double, the outer or ulnar element being comparatively small, while the inner or radial is very large, especially in Allactaga indica, where it occupies practically the whole of the posterior half of the sole. The pollex is a mobile cylindrical process, covered above with a large nail in Jaculus, Scirtopoda, Scarturus, and Allactaga, but in Euchoreutes, accoiding to Sclater, it is armed, like the other digits, with a long claw. This author also described the digits of Euchoreutes as long, but, judging from the figure, they are no longer than in other genera of Jaculidæ. As in several Rodents, notably the Squirrels, objects are held in the fore foot by folding the four digits back upon the large carpal pad, which plays the part, as it were, of a thumb. (Text-fig. 32, A.)

The fore foot of Pedetes is short and broad, and has five welldeveloped digits, all armed with long, stout, nearly straight claws - the pollex being like the others, but shorter. The digital pads are scarcely defined; and the under sides of the digits and the short area of the sole distal to the carpal pads are naked and granularly roughened. No trace of plantar pads remains. The carpal pads are remarkable and, so far as I know, unique. They are very large. The inner pad is an elevated thickened cushion, beset on the summit with minute spicules. The inner pad is laminate and normally fits closely against the outer pad, but is independently movable like a valve, so that a deep space separates the summits of the two pads. Its free edge, moreover, bears a fringe of long hairs. This modification suggests that the carpal pads are prehensile and aid in the grasping of food that is gripped by the digits with their long claws. These claws are no doubt also fossorial. (Text-fig. $35, \mathrm{~A}-\mathrm{C}$.)

From the following summary of the characters of the fore foot it will be seen that Pedetes stands apart from the other genera. It may be noted, however, that Sicista falls with the Jerboas and not with Zapus:-

a. Fore foot with well-developed pollex armed with a claw as long as on the other digits ; claws very long, stout, and straight; carpal pads separable and prehensile, the movable outer pad with fringe of long hairs

Pedetes.

$a^{\prime}$. Fore foot with short pollex armed with a nail or slender claw; claws of digits 2 to 5 long or short, but slender and curved; carpal pads normal, confluent, the outer immovable and not fringed.

b. Foot elongated and narrow, digits unevenly spaced, 3 and 4 in advance of 2 and 5 .

Zapus.

$b$. Foot short and broad, digits 2 to 5 evenly spaced.

c. Pollex armed with small claw (sec. Sclater)

$c^{\prime}$. Pollex armed with broad blunt nail

Euchoreutes.

Sicista, Jaculus, Scarturus, Scirtopoda, Allactaga. 


\section{The Hind Foot.}

The hind foot in Sicista subtilis, according to Tullberg's figure, is much broader and shorter than in Apodemus sylvaticus, but closely resembles in those particulars the foot of Rattus norvegicus. The hallux is shorter than in that species and closer to the second digit, and the second, third, fourth, and fifth digits are subequally spaced and close together, as in the fore foot, the third and fourth projecting a little beyond the second and fifth. The claws are short and the digital pads normal and semielliptical. The plantar pad is represented by four separated interdigital elements, the median being comparatively large and

Text-figure 33.

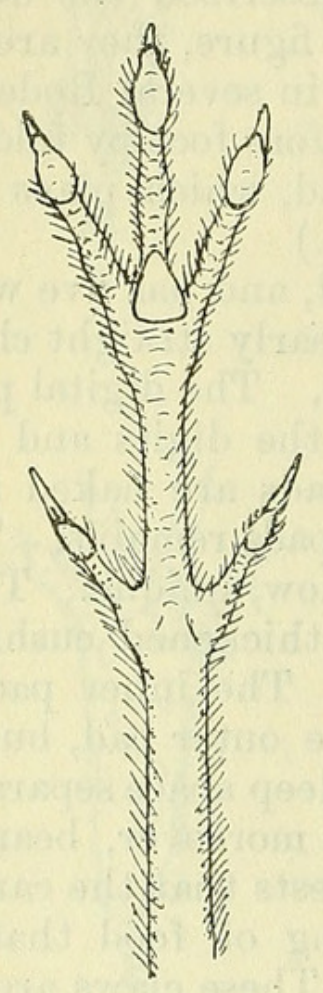

A

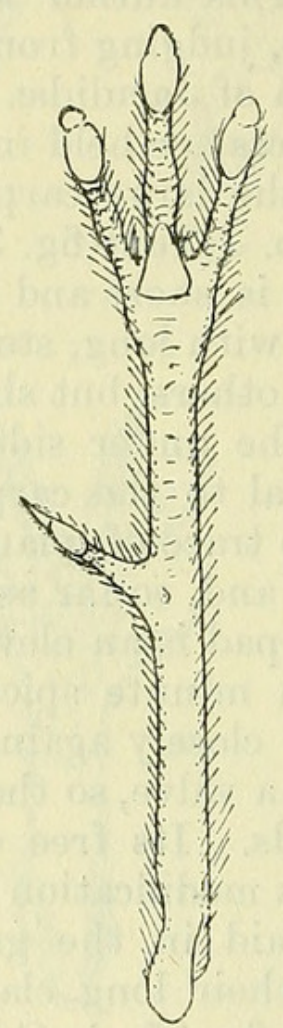

B

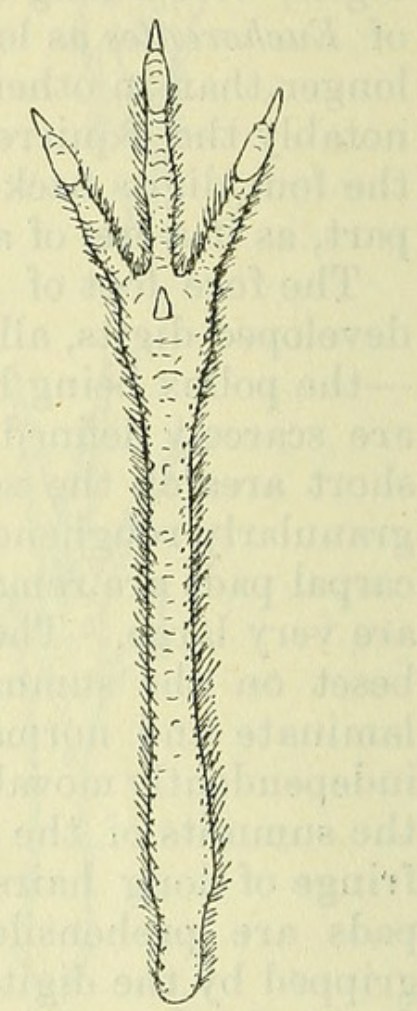

C
A. Right hind foot of Allactaga indica.
B. The same of Scarturus tetradactylus.
C. The same of Jaculus jaculus, with hair cut short.

triangular, the others much smaller and subcircular, the one at the base of the hallux being remote from the rest and only a little in advance of the external metatarsal pad, which is also quite small and subcircular, while the internal metatarsal pad is elongated and situated near the inner edge of the foot halfway between the heel and the hallucal element of the plantar pad. (Text-fig. 32, E.)

The hind foot of Zapus is very different from that of Sicista. It is very long and slender, the second, third, and fourth digits being well in advance of the first and fifth, with the second 
farther from the third than the latter is from the fourth, these two being closely united proximally. The hallux is moderately long and slender, and rises a little behind the origin of the fifth; it reaches to the base of the second, which is shorter than the third approximately by its digital pad; the fifth reaching only to the distal end of the narrow webbing tying the third and fourth closely together proximally. The claws are long and slender, and the digital pads elliptical. The plantar pad is represented by four small, isolated, subcircular, interdigital elements set on the granular sole in accordance with the disposition of the digits. The metatarsal pads are represented merely by the internal element, which is a small subcircular pad set one-third of the distance along the metatarsal area between the hallux and the heel. (Text-fig. 32, F.)

The hind feet of the Jaculidæ differ profoundly from those of Zapus in the disposition of the digits and other particulars. They are markedly perissodactyle, the third digit being the longest, set in the middle line, and symmetrically tlanked on each side by the second and fourth, which are equal in length and rise at the same level. Their digital pads are moderately or very large, deep, compressed, and laterally grooved, with lobulate distal edge. The plantar pad is represented by a larger or smaller soft median papilla; pointed apically. The metatarsus is much longer than in Zapus, and, as is well known, the three bones corresponding to the three main digits are completely fused into one. The first and fifth digits may be absent or present. When present they rise a long way back on the metatarsus, and, since they do not normally touch the ground, have been described as functionless. They are slender, with a small normal digital pad and thin longish claw. The metatarsal bone proper to each remains distinct from the median "cannon" bone, and, when both these digits are retained, they spring from the side of the metatarsus at the same level. Progressive reduction in the number of digits from five to three is shown in the family. In Pygeretmus, Allactaga, and Euchoreutes the first and fifth are retained. In Scarturus the first is lost and the fifth retained. In Jaculus both are lost. The under side of the digits varies greatly in hairiness. In the two Egyptian species, Jaculus jaculus and Scirtopoda orientalis, they are thickly fringed on each side with long hairs, which curve inwards over the under surface of the digits and form a soft hairy cushion. Close to the pads these hairs are exceptionally long. They quite conceal the median pad from the lateral aspect, but the pads of the second and fourth digits are not entirely covered by them. In these two hairyfooted species the median plantar papilla is very small and soft, and the digital pads are comparatively small. In Scarturus, which occurs in the same localities as Scirtopoda orientalis, on the contrary, the under sides of the digits have no long fringes, and the digital pads are very large and deep, and more strongly grooved and marginally lobate than in Scirtopoda orientalis and 
Jaculus jaculus. They conceal the claws from the lower aspect, of the foot, but these claws are smaller than in $J$. jaculus and S. orientalis. The plantar papilla, moreover, is a large conical eminence. The three main digits of Allactaga indica resemble those of Scarturus tetradactylus in the comparatively scanty development of hairs on the under side; but the pads do not appear to be so large*. Nevertheless, the plantar papilla is a large conical eminence as in scarturus. (Text-figs. 33, 34.)

In the four species of this group above described the claw of the median digit is considerably smaller than those of the lateral digits.

Text-figure 34 .
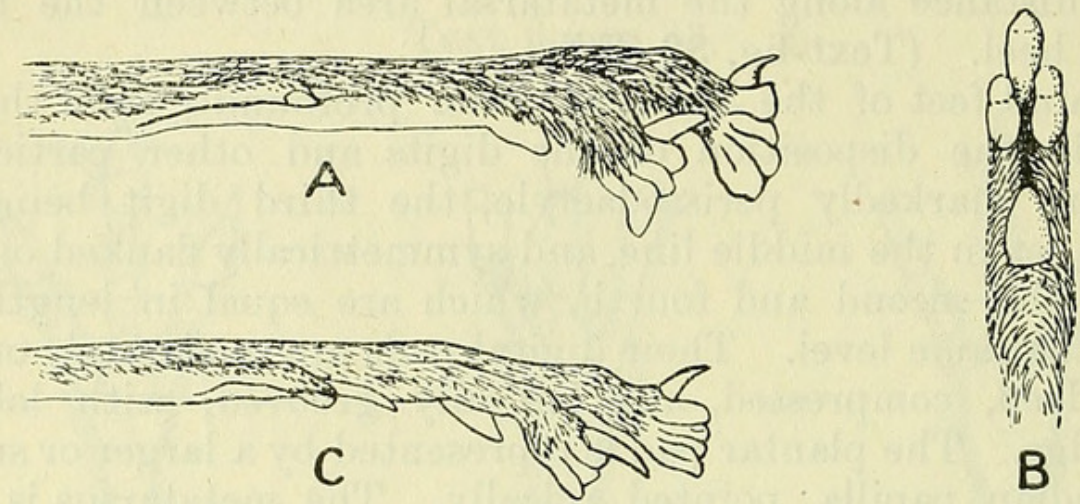

B
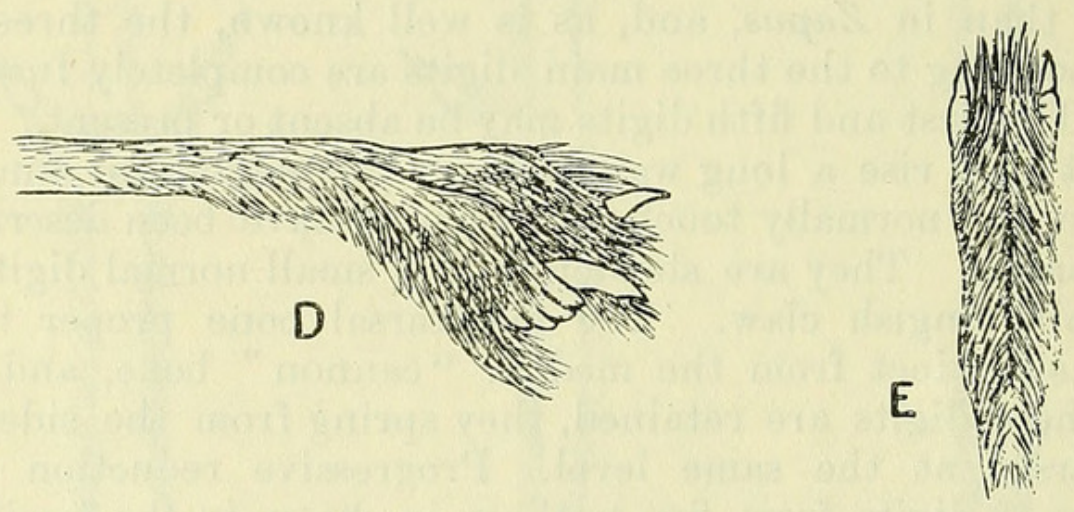

A. Right hind foot of Scarturus tetradactylus, from outer side.

B. Lower view of same, with digits closed together.

C. Right hind foot of Allactaga indica, from outer side.

D. The same of Scirtopoda orientalis.

E. Lower view of the same, with digits closed.

The hind foot of Pedetes, although saltatorial, has the metatarsus much shorter in relation to the length of the digits than in the Jaculidæ; but it resembles the hind foot of the latter in having the third digit the longest, set in the middle line, and flanked on each side by the second and fourth; and, as in the Jaculidæ, the under side of the digits and mostly of the metatarsus is naked, but covered with the hairs which overlap them from the sides. As in Scarturus, there are four digits, the first having entirely disappeared, while the fifth is retained. But, a art from

* The only specimen examined hau been for many years in alçohol, and possibly the pads were shrunken in size. 
these features, the foot is very different from that of all the genera of Jaculidæ. For instance, the fifth digit forms a uniform series

\section{Text-figure 35.}

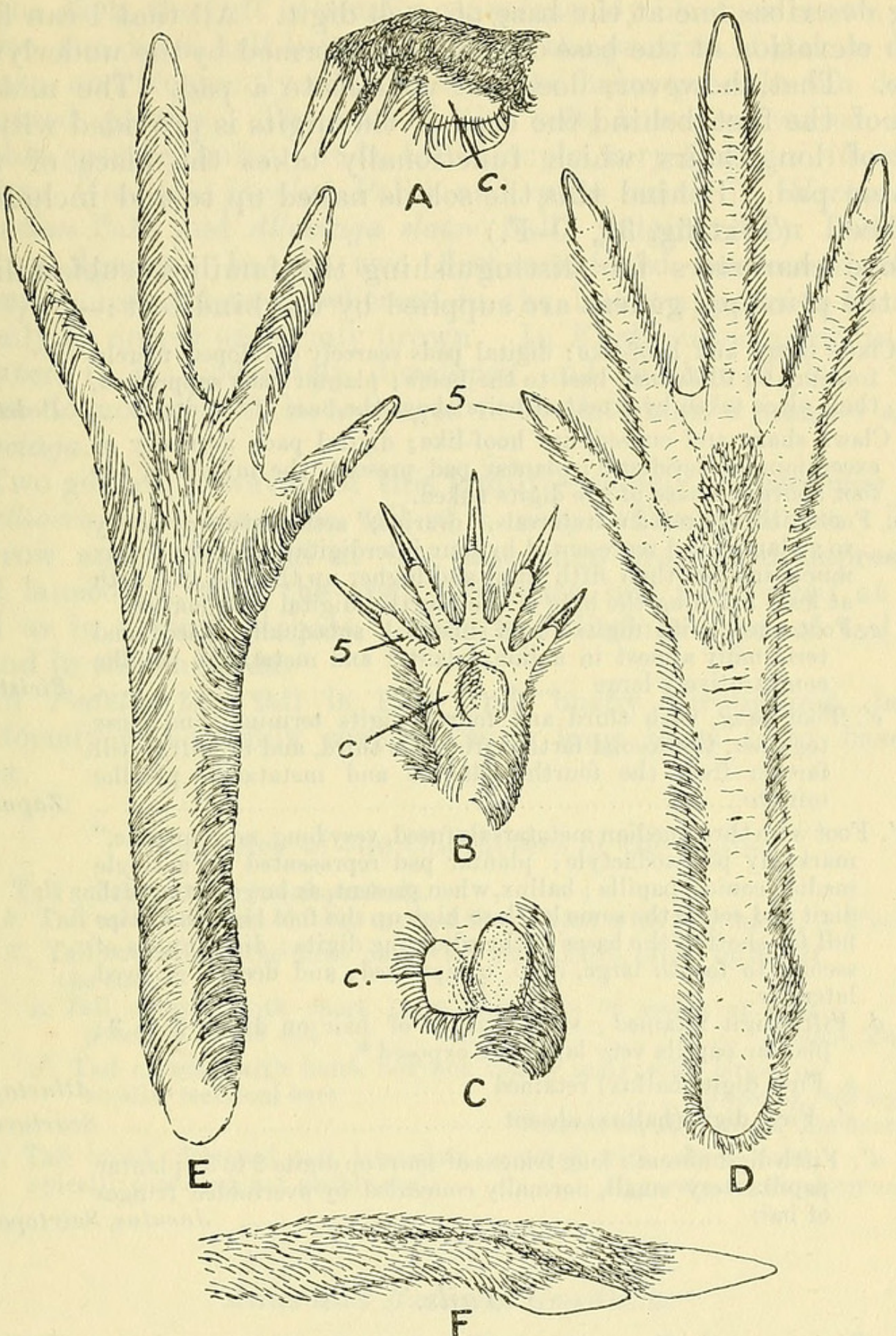

A. Left fore foot of Pedetes caffer, from outer side.

B. Right fore foot of the same, from below.

C. Two carpal pads of the same, spread (on rather larger scale).

D. Right hind foot of the same, with hairs cut short.

E. Left " " with hairs entire.

F. The same from outer side, showing fourth and fifth digits.

c., outer movable carpal lobe with fringe of hair ; 5 , fifth digit.

with the next, the space between it and the fourth being equal to that between the fourth and third or third and second, 
Again, the claws are broad and strong like pointed hoofs, and beneath are completely fused with the digital pads, which are represented merely by an ill-defined area constituting the heel of the hoof. I can find no trace of plantar pads, although Tullberg describes one at the base of each digit. All that I can find is an elevation at the base of each digit formed by the underlying bone. That, however, does not constitute a pad. The middle area of the foot behind the base of the digits is provided with a mat of long hairs which functionally takes the place of the plantar pad. Behind this the sole is nalsed up to and including the heel. (Text-fig. 35, D-F.)

Good characters for distinguishing the families, subfamilies, and the principal genera are supplied by the hind feet :-

a. Claws broad and hoof-like; digital pads scarcely developed, merely forming an ill-defined heel to the hoofs; plantar pads suppressed, their place taken by a mat of hairs above the base of the digits ...

$a^{\prime}$. Claws sharp and curved, not hoof-like; digital pads normally or exceptionally developed; plantar pad present, the middle of the foot above the base of the digits naked.

$b$. Foot with separated metatarsals, "murine," artiodactyle or nearly so ; plantar pad represented by four interdigital papillæ; hallux much smaller than fifth digit and higher up the foot, the fifth at least reaching the base of the fourth ; digital pads normal.

c. Foot short with digits 2 to 5 subequal, subequally spaced, and terminally almost in a line; plantar and metatarsal papillæ comparatively large

Sicista.

$c^{\prime}$. Foot long, with third and fourth digits terminal and close together, the second farther from the third, and the fifth still farther from the fourth; plantar and metatarsal papillæ minute.....

Pedetes.

$b^{\prime}$. Foot with three median metatarsals fused, very long, not "murine," Zapus. markedly perissodactyle; plantar pad represented by a single median conical papilla ; hallux, when present, as large as the fifth digit and set on the same level, so high up the foot that their tips fall far short of the bases of the adjoining digits; digital pads of second to fourth large, deep, compressed, and deeply grooved laterally.

d. Fifth digit retained; short fringes of hair on digits 2 to 3 ; plantar papilla very large and exposed *.

$e$. First digit (hallux) retained

$e^{\prime}$. First digit (hallux) absent

Allactaga.

Scarturus.

$d^{\prime}$. Fifth digit absent; long fringes of hairs on digits 2 to 3 : plantar papilla very small, normally concealed by overfolded fringes of hair

Jaculus, Scirtopoda.

\section{Tails.}

In Sicista and Zapus the tail is long, subcylindrical, tapering, and covered with scales and short hairs as in typical murine Rodents, the hairs at most forming a slight terminal pencil. In the majority of the Jaculidæ it is more definitely quadrate, covered with short hairs, not distinctly scaly, and is provided with a distinct terminal tuft, which, however, varies considerably in size. In Jaculus jaculus, Scirtopoda orientalis, and Scarturus,

* The hairiness of the feet in Allactaga may vary specifically according to habitat, 
for instance, the hairs of the tuft are long and show a marked tendency to a bilateral, distichous, or feather-like arrangement, apparently to give support and prevent the end sinking into soft sand when used as a prop; and probably for use as a guide-mark in the dark, the tuft is usually conspicuously black or brown and white, the distal half being white and the proximal black or deep brown, and frequently additional white hairs precede the darkcoloured portion. The size of the tuft, however, varies even within specific limits. It is, for example, very large in Allactaga saliens Gm. (= jaculus Pall.) and quite small in Alactagulus acontion Pall. and Allactaga elater Pall., judging from Lichtenstein's figures. In the two first-mentioned, moreover, it is conspicuously coloured, whereas in the last it appears to be uniformly or nearly uniformly brown. In Euchoreutes, according to Sclater, it is moderately developed and bicoloured, but "the hairs do not seem to be arranged in so distichous a manner as in Alactagu."

Two genera, howevor, of this family-namely, Pygeretmus and Cardiocranius - have the tail of a very different shape. It is narrow and cylindrical at the base, then broadened, depressed, and lanceolate, with the apex attenuate, but not tufted at the end as in typical Jerboas. Thus two distinct types of tail are found in the Jaculidæ.

In Pedetes the tail is long and bushy throughout, being uniformly and thickly covered with long hairs from base to apex.

\section{Summary of the Characters of the Tails.}

a. Tail subcylindrical or subquadrate.

$b$. Tail uniformly and thickly covered throughout with long hairs... Pedetes.

$b^{\prime}$. Tail covered for the most part with short hairs, often tufted at the end.

c. Tail cuvered with short hairs and rows of scales, at most pencilled at the end ................................ Sicista, Zapus.

$c^{\prime}$. Tail covered with hairs, but not visibly scaly, with larger or smaller terminal tuft ................................ Jaculus, Scirtopoda, Scarturus, Allactaga, Euchoreutes.

$a^{\prime}$. Tail broad, flattened, and lanceolate, covered with short hairs, apically pencilled, not visibly scaly

Pygeretmus, Cardiocranius.

\section{Anus and External Genitalia.}

In Zapus the anus, as in most Rodents, opens in the centre of an area of naked skin above the genital orifice, the two orifices being separately visible on superficial inspection. In the female the vulva is, however, just below the anus and the naked skin surrounding it is continuous above with that surrounding the anus. There is no elongated, conical, preputial excrescence and no visible external clitoris. In the male the penis, normally retrospective, is separated by a fringe of hair from the anus

Proc. Zool. Soc.-1922, No. XLVI. 
Text-figure 36.

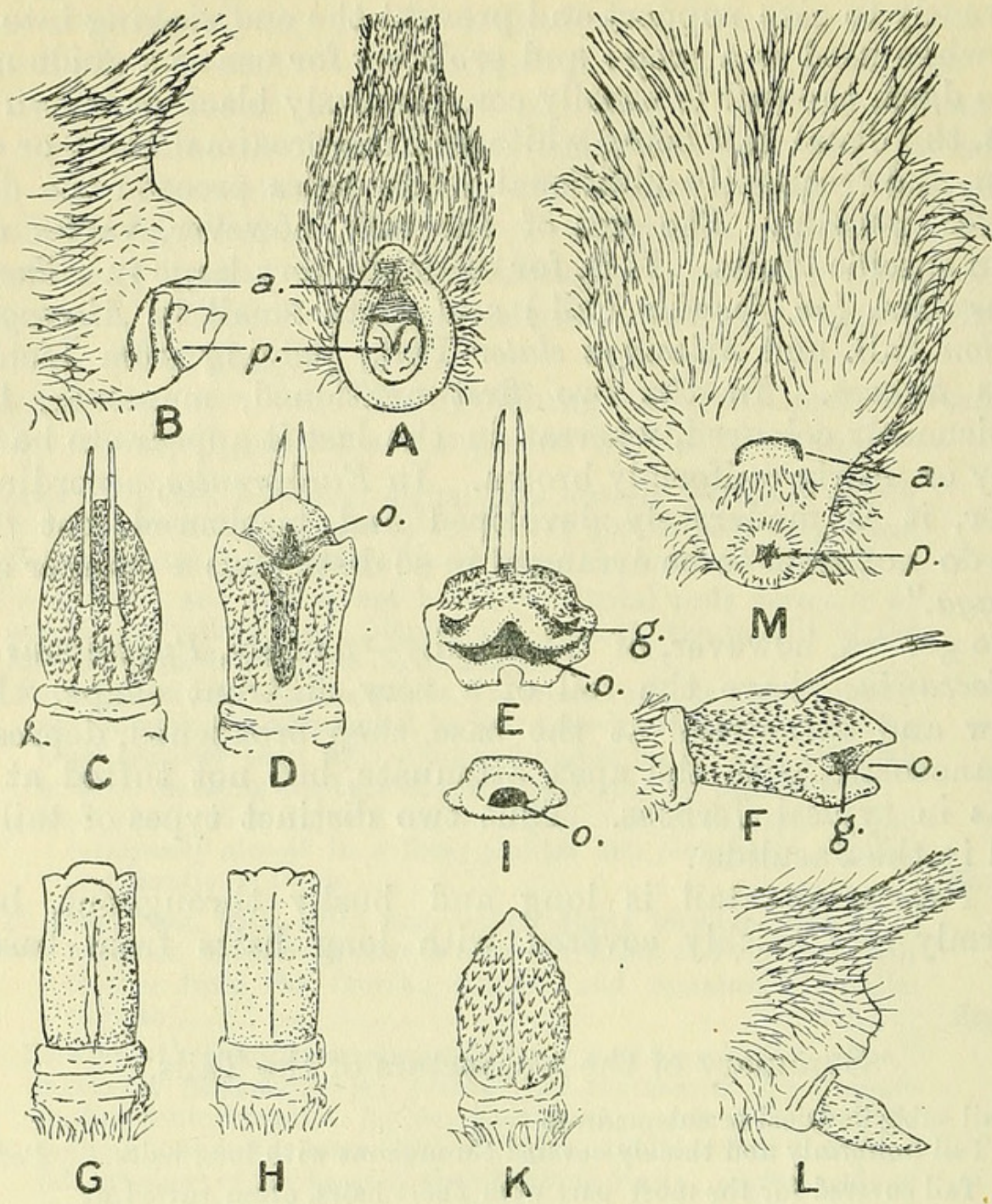

A. Rear end of Scirtopoda orientalis, from behind, with the anal lobe raised to show the anal orifice $(a$.) above the penis $(p$.$) .$

B. The same from the side, with the anal lobe in natural position and the penis $(p$.$) partially protruded.$

C. Upper side of glans penis of Scirtopoda orientalis, with spikes lying forwards.

D. Lower view of glans penis of the same, with apex dilated.

E. Dilated tip of glans penis of the same from the front, with spikes raised.

F. Side-view of glans penis of the same, with spikes partially raised.

G. Upper view of glans penis of Jaculus jaculus.

H. Lower view of the same.

I. Tip of glans penis of the same, from the front.

K. Upper side of glans penis of Scarturus tetradactylus.

L. Rear end of S. tetradactylus, with glans partially protruded.

M. Rear end of Pedetes caffer, from behind, with crescentic anus above penis.

a., anus; g., glandular pit in penis of Scirtopoda orientalis; o., genito-urinary orifice; $p$., penis. 
above, and its glans is slender and subcylindrical, according to Tullberg *.

In all the specimens of Jaculidæ examined the anal and generative orifices are so closely applied that on superficial inspection there appears to be a single orifice only, situated upon a thick naked excrescence a little distance below the root of the tail. In the females, indeed, the vulva and anus are slightly insunk, and are closed by a common sphincter. In the males the tip of the penis in its natural position is pressed up against the lower side of the anal prominence which carries the anal orifice, concealed from view, on its underside. This prominence is exceedingly large in Scirtopoda orientalis (text-fig. $36, \mathrm{~A}, \mathrm{~B}$ ).

The penis of Scirtopoda orientalis was first described by Sonnini $\dagger$ and Olivier $\div$. The glans is large and oval in shape, and is thickly covered with many backwardly directed short spines; but, in addition, it is armed with a pair of long slender stiliform spikes, like those in the pouch of the glans of Cologenys, Cavia, and some other Hystricomorphs. These spikes are rigid, except at the tips, which are soft. According to Sonnini, these tips form a small yellow button like the anther's of certain flowers; but in the specimens examined by me they were pointed and only distinguishable by their softness from the rest of the spike. Normally these spikes lie forwards upon what is the upper side of the penis when this organ is extended from the prepuce and directed forwards, and their tips overlap the apex of the glans; but they are capable of being elevated or even directed backwards. Beneath the narrowed apex of the glans the large orifice, which has an upper and a lower lip, opens, and on each side of it there is a shallow, probably glandular, pouch. The lower side of the glans is provided with a median, probably glandular. gutter, the edges of which, when brought together, form a narrow lineal crease (text-fig. 36, C-F). In Jaculus jaculus the glans penis is very different, as Anderson and de Winton pointed out. It has no spikes, and the small spines seen in Scirtopoda orientalis are represented by minute pits, in each of which there is sunk a scale with serrulate free edge. There is a median thickening on what is the upper side of the penis when this organ is turned forwards, and there is a narrow median groove below. There is a curved groove above the upper lip of the orifice and a small prominence on each side of it, but no glandular depression. (Text-fig. 36, G-I.)

In Scarturus the glans is oval or cordate from above or below, pointed from the side-view, and the terminal orifice is simple. It is armed with sharp recurved spines, which are fewer in number and relatively larger than in Scirtopoda orientalis, but there is

* In the specimen I examined the tip of the glans was covered with an extraneous thickening of hard material closely adherent to it.

+ Voy. en Egrpte, i.pp. 173-174 (1800).

‡ Bull. Soc. Phil. Paris, ii. no. 40, p. 121 (1801). 
no trace of the pair of long spikes seen in the latter species. According to the descriptions of Olivier and Tullberg the glans penis of Allactaga saliens closely resembles that of Scarturus. (Text-fig. 36, K, L.)

The anus and genitalia of the male of Pedetes caffer were described and figured by Calori *. To his account Tullberg had nothing to add. The anus is situated a long way below the root of the tail, much farther than in the Jaculidæ, and the prepuce of the retroverted penis forms a conical prominence beneath it. Superficially the anus appears as a crescentic slit, with the concavity downwards; and this appearance results from the downward growth of the skin of its upper border forming a flap over the anus itself. Calori described a gland-opening in the middle line of the perineum between the anus and the penis. This does not appear to me a very appropriate description, because no orifice is visible on the area named. There is, however, the orifice of a gland-opening within the prepuce just above the urino-genital orifice when the penis is retroverted and at rest. The penis itself is elongated, compressed, and covered with minute spicules; but there is no trace in it of the glandular pouch which is so characteristic of the Hystricomorphs. (Text-fig. 36, M.)

a. A large gland-opening within the prepuce of the male on the anal side of the genito-urinary orifice; anus in the form of a crescentic slit some distance above the pen is ................................. Pedetes.

$a^{\prime}$. No preputial gland on the anal side of the genito-urinary orifice of the penis; anus not crescentic in shape.

b. Anus exposed above the tip of the penis, which is not tucked up

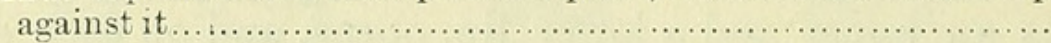

$b^{\prime}$. Anus concealed beneath an excrescence, to the under side of which the tip of the penis is applied.

c. Glans penis spiny with two immense erectile spikes Scirtopoda: $c^{\prime}$. Glans penis without spikes.

$d$. Glans penis elongated, parallel-sided, covered with minute pits, each provided with a serrate scale

$d^{\prime}$. Glans penis ovate, armed with spines

Jaculus.

Zapus.

\section{The Skull of Scarturus.}

The skull and dentition of Scarturus agree in essentials with those of Allactaga, and differ in many points from those of Jaculus - that is to say, the incisors are ungrooved and slightly projecting, though not nearly so strongly as in $A$. indica, for example; the minute upper premolar is retained; the zygomatic arch is comparatively slender where it forms the anterior wall of the orbit; the channel for the nerve is formed by a deep notch in the floor of the antorbital foramen and not a closed tube as in Jaculus; the auditory bullæ are much less inflated than in Jaculus, despite the large size of the ears, and the mastoid is not visibly inflated. I cannot, indeed, find any generic characters to

* Mem. Accad. Sci. Bologna, v. pp. 297-298 (1854). 
distinguish the skull of Scarturus from that of Allactaga, unless it be the lesser prominence of the incisor teeth and the presence of

Text-figure 37.

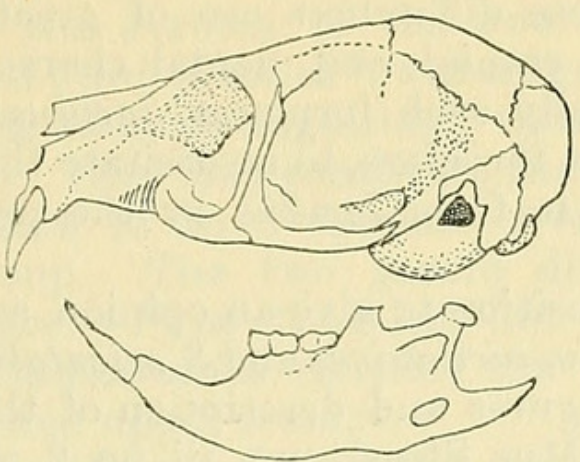

A

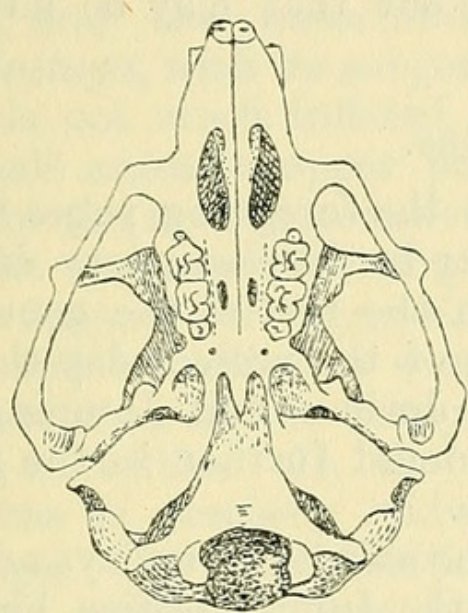

B

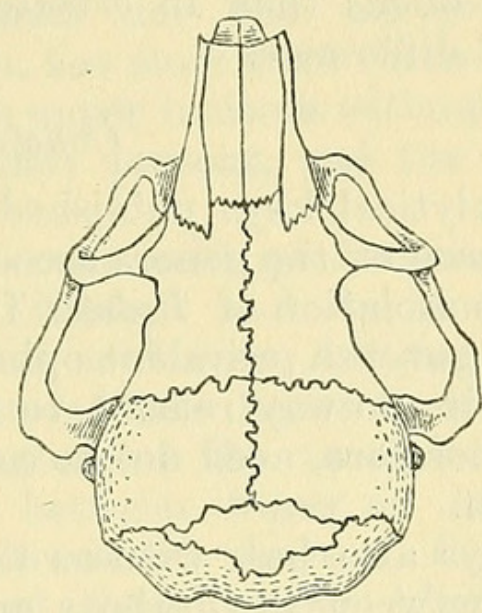

C

A. Skull of Scarturus tetradactylus, from the side.

B. The same, from below. The molar teeth which were out of the skull are diagrammatically represented.

C. The same, from above.

a longish median process projecting backwards from the palate over the mesopterygoid fossa, a character observed in the one skull of Scarturus examined.

\section{The Genus Scirtopoda Brandt.}

In his selections of the type-species for some of the genera and subgenera introduced into the family Jaculidæe by the older authors, Thomas cited Dipus mauritanicus Duv. as the typical representative of Brandt's genus Scirtopoda and also of its subgenus Haltomys (Ann. Mag. Nat. Hist. (8) ii. p. 308, 1908). He also stated that mauritanicus is identical with or closely allied to the large Egyptian Jerboa described by Olivier as Jaculus gerboa, the species quoted as Jaculus orientalis in the preceding pages of this paper. Except that the ears are relatively and the bodily size actually larger in this species than in Jaculus jaculus and the 
colour slightly different, I can find no difference between the two in external characters to which I should attach generic value. In dentition and cranial characters they are also much alike. But the external genitalia of the male are profoundly different. In my opinion these differences are of greater systematic importance than the cranial and dental characters employed for separating generically such forms as Jaculus jaculus and Dipus sagitta*. I propose, therefore, to resuscitate the genus Scirtopoda Brandt, separating it from Jaculus by the peculiar armature of the glans penis.

I am not in a position to give an opinion as to the suggested identity between $S$. marritanicus and S.orientalis; but Duvernoy's and Lereboullet's figures and description of the penis of manritanicus (Mém. Soc. Mus. Strasbourg, iii. no. 2, p. 48, pl. iv. fig. 12, 1842) show that that organ is of precisely the same nature as in orientalis. The spikes on the penis appear, indeed, to be shorter in mauritanicus than in orientalis, but that may be merely an individual difference.

\section{Conclusions.}

The analytical keys published in the foregoing pages to show the incidence of the genera according to the characters described attest the isolation of Pedetes from the rest of the genera, and thus bear out the prevalent opinion of the present day that that genus is in no way related to the Jerboas and Jumping Mice. Pedeies, therefore, need not be considered further in the present connection.

The keys also bear witness to the affinity nowadays admitted to exist between the Jerboas and the Jumping Mice, but show that the two may be sharply distinguished by the structure of the hind feet.

In 1901 Lyon (Proc. U.S. Nat. Mus. xxiii. p. 666), using skeletal (mainly cranial and dental) characters, classified the Jerboas and Jumping Mice as follows :-

Family Z A P O D D

Subfamily Sminthinж (Sminthus, ? Eomys).

"Z Zapodine (Zapus, Napceozapus, Eozapus).

Family D I P O D I X.

Subfamily Dipodine (Dipús, Allactagı, and probably Platycercomys).

, Euchoreutin (Euchoreutes).

* I am aware that the use of soft parts for differentiating genera of Mammals may be an annoyance to modern systematic mammalogists, who, following the fashion set in the United States, like to work from dried skins and skulls. But, although the zoo-geographical and other results obtained from that method are of great value and interest, 1 am sure that the sooner the swing of the pendulum carries us back to the method in vogue thirty years ago of working from fresh or spiritpreserved material, combined with skins, the better it will be for the science of mammalogy. 
Apart from the alterations necessitated by the nomenclature now in vogue and the addition of several recently proposed or recently restored generic names to the Jerboa family, I have no modifications of this classification to suggest, except the severance from the rest of the Jerboas of the two genera Pygeretmus (Platycercomys) and Cardiocranius*, which agree in having broad, flattened, lanceolate tails, distinguishing them at once from the rest of the family. They may constitute the subfamily Pygeretminæ, which appears to be a specialised offshoot of the fivetoed Allactaga-group. The two genera differ at least in the following characters:--Pygeretmus has lost the anterior upper premolar, which Cardiocranius retains; the latter has grooved, the former ungrooved upper incisors.

Lyon divided his Dipodinæ into two groups: (1) Dipus, with its subgenera, possessing three toes, a considerably inflated mastoid, the upper incisor grooved, the anterior upper premolar absent, and the antorbital canal for the nerve complete. (2) Allactaga, with its subgenera, has more than three digits, the mastoids not much inflated, the upper incisors without grooves, the small anterior upper premolar present, and the antorbital canal for the nerve incomplete.

If the above-mentioned characters held good there would be strong reasons for separating Allactaga and its kindred from Dipus and its allies as a special subfamily Allactaginæ. But there seem to be too many intermediate forms to make such a course advisable. In the number of the toes, for instance, Scarturus is precisely midway between Dipus or Jaculus and Allactaga. In the Asiatic three-toed Jerboa, Dipus $े$, the mastoids are much less inflated than in the African forms, Jaculus and Scirtopoda; Dipus thus connects those genera with Allactaga in that particular. In Dipus, too, the anterior small premolar is retained as in Allactaga, whereas it is lost in Jaculus and Scirtopoda. On the other hand, the small five-toed Asiatic Jerboa, Alactagulus acontion, resembles the three-toed African genera, Jaculus and Scirtopoda, in the loss of this molar.

Of the characters mentioned by Lyon, therefore, there remain as distinctive only the presence or absence of the grooves in the

* Satunin, Ann. Mus. Zool. St. Petersb. 1902, p. 582. The genus Cardiocranius has an extraordinarily wide and inflated cranial portion of the skull, which, as compared with the facial portion, is much larger even than in Euchoreutes. I associate this genus with Pygeretmus on the assumption that the peculiarly modified tail has not been developed twice independently within the group.

+ For the sense in which this genus is here used, sagitta being its type-species, see Thomas, Ann. Mag. Nat. Hist. (8) ii. p. 308 (1908). Trouessart seems to have been unaware of this paper by Thomas when he published his 'Faune des Mamm. d'Europe' in 1910. At all events, he proposes the new name Dipodipus for the group of Asiatic three-toed species, with sagitta as the type, for which Thomas showed the old name Dipus to be available. Satunin seems to have come in. dependently to the same opinion on this point as Thomas (Mitth. Kankas. Mus. 1907, p. 72). Trouessart also resuscitated Scirtopoda in quite a different sense from that in which Thomas employed it (cf. supra, p. 679). But, since Thomas was the first reviser of the nomenclature of these Jerboas, I follow his decisions. 
upper incisor teeth and the closed or open canal for the antorbital nerve. I am not aware whether these are constant differences.

Adopting Lyon's classification with the modifications above mentioned, the families and subfamilies of Jumping Mice and Jerboas will be as follows :-

I. Family Z A P O D I D

1. Subfamily Sicistin ${ }^{*}=$ Sminthine (Sicista).

2. , Zapodine (Zapus, Napceozapus, Eozapus).

II. Family JA C U L I A Or DIP ODID

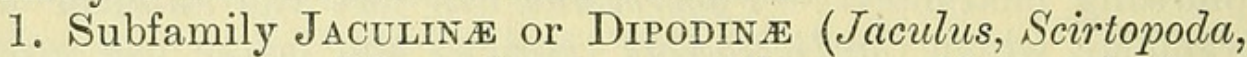
Dipus, Scarturus, Allactaga, Alactagulus).

2. $\quad$ Pygeretmin (Pygeretmus, Cardiocranius).

3. " Euchoreutina (Euchoreutes).

The chief distinguishing characters of the Zapodidæ and Jaculidæ and of the Sicistinæ, Zapodinæ, and Euchoreutinæ may be found in Lyon's paper. Those of the Pygeretminæ are stated above. With regard to the Jaculinæ, the genera which appear to me to be admissible, though there may be others, may be distinguished as follows :-

a. Five or four toes on the hind foot; incisors ungrooved; antorbital nerve-canal open above.

b. Five toes on foot, hallux present.

c. Small upper premolar retained Allactaga.

$c^{\prime}$. Small upper premolar lost .............................. Alactagulus.

$b^{\prime}$. Four toes on foot, hallux lost (skull and dentition as in Allactaga)....

Scarturus.

$a^{\prime}$. Three toes only on hind foot; incisors grooved; antorbital canal closed above (? always).

d. Small upper premolar retained; mastoids less inflated

Dipus.

$d^{\prime}$. Small upper premolar lost; mastoids much inflated.

$e$. Glans penis without spikes, with insunk scaly armature

Jaculus.

$e^{\prime}$. Glans penis with a pair of large erectile spikes and spinous armature.

Scirtopoda.

* See Miller, Cat. Mamm. Western Europe, p. 536 (1912). 


\section{$2 \mathrm{BHL}$ Biodiversity Heritage Library}

Pocock, R. I. 1922. "The External Characters of Searturus and other Jerboas, compared with those of Zapus and Pedetes." Proceedings of the Zoological Society of London 1922, 659-682.

https://doi.org/10.1111/j.1096-3642.1922.tb02163.x.

View This Item Online: https://www.biodiversitylibrary.org/item/100613

DOI: https://doi.org/10.1111/j.1096-3642.1922.tb02163.x

Permalink: https://www.biodiversitylibrary.org/partpdf/72053

\section{Holding Institution}

Smithsonian Libraries

\section{Sponsored by}

Biodiversity Heritage Library

\section{Copyright \& Reuse}

Copyright Status: Public domain. The BHL considers that this work is no longer under copyright protection.

This document was created from content at the Biodiversity Heritage Library, the world's largest open access digital library for biodiversity literature and archives. Visit BHL at https://www.biodiversitylibrary.org. 